\title{
Determinants and consequences of disruptive innovations: E vidence from the UK financial services sector
}

\author{
Tasawar Nawaz ${ }^{\text {a,1 }}$ \\ aUniversity of Plymouth, United Kingdom
}

\begin{abstract}
A bstract: Building on the assumption that intangible and tangible corporate resources are indispensable to create and sustain firm value in today's knowledge driven economy; this paper empirically examines the determinants and consequences of disruptive innovations in the context of the UK financial services sector. The major contribution of this paper is to provide novel insights into the value creation process in one of the world's leading financial services sector. In doing so, the paper exploits various properties of the selected financial institutions and submits that financial and human capital resources drive value in the UK's financial services sector. The paper makes informed suggestions for the financial institutions operating in the UK and abroad. The results observed in the present study will potentially enhance the understanding of the international audiences on the banking business model practiced by the UK-based financial institutions.
\end{abstract}

Keywords: disruptive innovations, corporate resources, intellectual capitalbased view, firm value, UK Financial services sector, Brexit.

J EL codes: C12, G15, G20, G21, G24.

\section{Introduction}

The general landscape of business has changed in the past one hundred years. The change is mainly driven by the disruptive innovations during the century. Christensen coined the term and theory of disuptive innovation in the mid-1990s.

1 Department of Accounting, Economics and Finance, Plymouth Business School, University of Plymouth, United Kingdom, e-mail tnawaz@plymouth.ac.uk. 
According to Christensen (2013) disruptive innovation is "a process by which a product or service takes root initially in simple applications at the bottom of a market or in a new market, and then relentlessly moves 'up market', eventually displacing established competitors". Charitou and Markides (2002) further explains that "disruptive strategic innovation is a specific type of strategic innovation namely, a way of playing the game that is both different from and in conflict with the traditional way". Examples of disruptive strategic innovations include but are not limited to online brokerage trading, direct insurance, low-cost airlines and Internet banking.

Businesses have largely adopted the new technologies to expand their portfolios mainly for affiliated economic benefits (Nagy et al., 2016; Y u and Hang, 2010). The pursuit of profit maximisation has also led to the misuse of the concept of disruptive innovations in certain sectors. Financial services firms such as banks are one of the key examples in which disruptive innovations were exploited to maximise financial returns. The sector introduced high-risk financial products such as collateralised debt obligations (CDOs), which proved to be a non-disruptive innovative product that among other hazardous financial products led to the financial crisis (Crotty, 2009). Despite the role of financial institutions in causing the financial malaise, some aspects of financial services firm remain largely unexplored to date. One such question is that how such firms create value using the avai lable corporate resources at their disposal?

The journey of disruptive innovations in the UK financial services sector started with the Telephone banking in 1989, followed by personal computer (PC) banking in 1996 and Online banking in 1997 (Charitou \& Markides, 2002). Today, UK is known for its financial services, which are virtually exported to the whole world. The current economic and political uncertainty caused by the vote to leave the European Union (EU) or the so-called Brexit has posed varying threats to the UK's services sector in general and financial services sector, in particular (Edmonds, 2018). According to the latest figures released by the House of Commons (see Rhodes, 2018), the financial services sector contributed more than $f 100$ billion (around $7 \%$ of total economic output) to the UK economy in 2017. The sector employed over one million people or around $4 \%$ of all jobs in the UK. In terms of tax contributions, the sector contributed around $£ 30$ billion in tax in the last fiscal year. These figures highlight the significance of the UK financial sector in the times of economic and political uncertainty, which qualifies, for further empirical investigation.

Furthermore, as the UK prepares to leave the EU, the largest financial services exports market in which the EU received about $45 \%$ of the total financial services exported by the UK based financial services firms in 2017, the implications of the divorce between the UK and EU are unneglectable. Economically speaking, the 
degree of inter-linkage between the UK and the EU economies is substantial and intricate in terms of the legislative interface. The UK's financial sector is vulnerable as the bids to compete for the next world's financial hub are on the rise where the main competition is coming from Paris, Frankfort, Dublin, and Warsaw who are ready to topple London.

All these factors beg for more exploration and analysis of the UK financial services sector, which provides an ideal setting to conduct the current research. The anal ysis of determinants of disruptive innovations and their impact on profitability will offer better insights into the UK financial services sector. The results observed in the present study will potentially help the UK financial services sector to capitalize on the corporate resources, which has hel ped the industry to remain competitive in past as well as the results will enhance the understanding of the international audiences on the banking business model practiced by the UK banks.

The paper is structured as follows. Notable disruptive innovations in the past century are traced in sections 2 alongside corporate resources (viz. human, organizational and financial capital) required to crate value in today's knowledge era. The nexus between disruptive innovations and firm value, criterion and predictor variables, and research sample are presented in section 3. Section 4 provides the statistical analysis whereas concluding remarks are submitted in section 5.

\section{Disruptive innovations and corporate resources}

This session is divided into parts. The first part puts on glance some of the notable disruptive innovations in the past one hundred years, which has transformed the way business is conducted today. Corporate resources essential for business and banking business, in particular are subsumed in the second part. This is followed by the research hypotheses to be tested in the present study.

\subsection{Disruptive innovations - a pitch}

Disruptive innovations range from the invention of Television and Mobile Phone in the $20^{\text {th }}$ century to the invention of Internet and the social media in the first decade of the twenty-first century. Television provided an initial breakthrough for businesses to reach out to the household in a visual form, which appealed more people as compared to the previous versions of marketing instruments and platforms such as newspapers and gadgets (Nagy et al., 2016). Printed and visual media are still playing a key role in promoting businesses however, additional innovations have added value.

One such example is of Mobile Phones, materialised in the 1970's have proved to be another breakthrough. The innovative breakthrough not only helped businesses 
to grow but also the telecommunication have become one of the main economic sectors in any country economy. What is interesting to note is that the TV and Mobile phones have had limited accessibility (county or region specific) and the technology was expensive therefore, not all the businesses could afford such technology, especially the small and medium (SME) sector. It is important to note that these technologies mainly benefitted the business but not to the clients or household in terms of control over the contents and reliability of the information. The invention of internet in the 1990's hugely contributed in addressing these concerns. The technol ogy enabled the business to sell their products and services in a cross boarder manner without physical ly being present in a market. This is when business realised the concept of outsourcing when they discovered the cost efficient market in term of labour supply and demand. The extensive use and reliability on this technol ogy al so created artificial bubbles. The dotcom boom bust of the early 1990s is one of the key examples.

The journey of disruptive innovations not only continued but it has intensified with the beginning of the new millennium Apple, for example, adopted a disruptive innovative business model to build an ecosystem of app developers so as to debut the first iPhone in 2007, which proved to be an al ternative of a personal computer. Apple targeted the same customers coveted by incumbents, and the success of iPhone is explained by product superiority in being a disruptive innovative product not to compete with other smartphones but in changing the whole landscape of how people accessed internet -i.e. via the computers or laptops, echoing (Christensen et al., 2015).

At the same time businesses kept adopting the new technologies to expand their portfolio hence, profits while taking advantage of their local (at country level) and international rivals (Nagy et al., 2016; Yu \& Hang, 2010). The pursuit of profit maximisation also encouraged individuals and businesses to exploit disruptive innovations such as product and services development in certain sectors. Financial services firms such as banks are one the key examples in which disruptive innovations were exploited to maximise financial returns. The sector introduced high-risk financial products, which led to a financial crisis. The after effects of the financial malaise are still felt in the form of austerity in many modem economics around the world (Nawaz, 2015).

The 10th anniversary of the Great Financial Crisis (GFA) has just passed in 2017. The GFA, which initially engulfed the country economies of Americas and Europe, later spread to include the Middle Eastern and Asian economies has affected every sector within the economy. The impact of GFA however, centred on the services sector and banking firms in particular, which are held responsible to create the financial bubble. Empirical evidence on the causes and impact of the financial crisis have been well documented in the literature (Nawaz, 2017c; Nawaz, 2016a). 
Against this background, the main purpose of this paper is to present an empirical evidence from the United Kingdom's financial services sector by analysing the resources of competitive advantage and value creation in the UK banking sector.

\subsection{Corporate resources}

Reed et al. (2006) introduced the intel lectual capital-based view (ICV) of the firm which mainly consists of human, organisational and social capital. Human capital is the thinking capital referred to as the human intellectuality to create new innovative ideas (Nawaz, 2017a; Nawaz, 2017e). Organisational capital is the nonthinking, supporting capital (Nawaz, 2016a) and social capital, which in financial terms refers to corporates relations with lenders (the principal) and clients, necessary for corporates seeking financing opportunities (Uzzi, 1999).

In this study, it argued that val ue creation is a combination of the above-mentioned resources. Financial, human, and organisational capital interact to create val ue for a firm These corporate resources are highly significant to every business but they have special reference to services firms such as banks as they are overly exposed, given their recent role in creating the worst financial crisis of modern times.

\section{Financial capital and disruptive innovation}

Firms need financial capital resources to conduct business (Uzzi, 1999). Financial capital enables a firm to rent human capital and to buy organisational capital resources in order to create value for a business through various processes. Organisations, financial institutions in particular, whose main business is to deal in money, profoundly rely on financial capital (Nawaz and Haniffa, 2017; Nawaz, 2013b; Subramaniam and Youndt, 2005). It is therefore, argued that efficient allocation and deployment of financial resources contributes to disnuptive innovations, which leads up to higher firm value, measured by the financial performance of the selected banks.

Hypothesis 1: Ceteris paribus, financial capital relates positively with profitability measured by ROA

\subsection{Human capital and disruptive innovation}

Human capital refers to an individual's intellectual ity, which largely consists of but not limited to knowledge, abilities, attitudes, skills and experience. In other words, human capital refers to the personal capital attributes embedded in and inseparable from an individual. An individual can rent them out to a business or an organisation, which can be exploited to create value for the firm (Edvinsson \& Sullivan, 1996). Furthermore, the ownership of these attributes cannot be transferred hence, they stay with the bearer. Simply stated, when an individual leaves the workplace these skills leave out with that individual (Nawaz \& Goj, 2013; Reed et al., 2006). Hence, they are not owned by the business. 
Accordingly, it is argued that human capital is at the centre of creativity and innovation, including disuptive innovations in any sector and services sector, in particular. Therefore, it is expected that human capital contribute to disruptive innovations, which leads to higher firm value, measured by the profitability (i.e. ROA) of selected banks analysed in the present study. This is consistent with the intellectual capital-based view (ICV) of the firm which argues that human intellectuality is at the core of value creation process (Nawaz, 2017d; Reed et al., 2006). Accordingly, the following hypothesis is extended;

Hypothesis 2: Ceteris paribus, human capital relates positively with profitability measured by ROA

\section{0rganizational capital and disnuptiveinnovation}

Subsumed under organisational capital are both tangible and intangible assets. They range from buildings (offices), desks, machines, computers and so forth to copyrights, software, and intellectual property rights. A combination of hard- and soft-resources help human capital to work better (Subramaniam \& Y oundt, 2005). Organisations use these resources to convert the intangible ideas into tangible products or services (Nawaz \& Haniffa, 2017; Nawaz, 2017c; Nawaz \& Goj, 2013). As oppose to human capital all organisational capital resources are owned by the business (Nawaz, 2017a; Nawaz, 2015). To clarify the difference between human and organisational capital resources; individual attributes that leave the organi sation with the individuals at the end of a business day are human capital and whatever stays back in the tangible or intangible form within the organisation is largely defined as organisational capital (Nawaz, 2013a). Organisational capital assists human capital in the value creation process.

Hence, organi sational capital's role is equally important in the process of disruptive innovation. Accordingly, tuned by the intellectual capital-view of the firm, it is hypothesised that organisational resources contribute to disruptive innovations, which leads to higher firm value, measured by the financial performance of sel ected banks included in the present study.

Hypothesis 3: Ceteris paribus, organisational capital relates positively with profitability measured by ROA

\section{Disruptive innovation and firm value}

As argued above, disruptive innovation leads to firm value creation. There are different ways to look at the value creation of a firm Value is viewed differently by every business. For instance, for a charity value is creating better social work for the society whereas a pure educational institution may argue value is exploring, generating, sharing, and contributing to the body of knowledge. Similarly, value creation could be seen as pure profit, in financial terms. This study adopts this approach to measure the impact of corporate resources outlined as human, organisational and financial capital on profitability of sampled banks operating in the UK. 


\subsection{Significance of the UK financial sector}

Financial sector is considered as the backbone of any country economy. Financial institutions such as banks perform the function of well-oiled machines that run the economy in an efficient manner. By function or operational isation, banks increase the economic activity within an economy by efficiently allocating the surplus financial resources from those who save (i.e patient household, in economic terms) to those who seek funds (i.e impatient household, in economic terms) for an economic activity through the function of financial intermediation. Although the liberalisation of the economies around the world and globalisation has brought loads of opportunities for businesses, including the financial services firms to grow by catering a larger market in a cross-border manger, it has also exposed these firms to several unanticipated challenges. One such challenge is the intensified competition within the financial services sector. Banks in the UK, for instance, are not only competing with those counterparts operating within the country but also with the other international players.

This makes the financial services sector an interesting sector to conduct an empirical study. As stated above, UK is one the largest financial services exporter in the world. The currently political uncertainty brought about by the Brexit vote is threatening London's status as of world's financial hub. The economic and social effects of losing the largest export market (i.e. the EU) are huge for the UK. Therefore, it is imperative to analyse the determinants and consequences of disruptive innovations within the UK financial sector and propose guidelines for the sector to sustain its compatibility.

\subsection{Predictor and criterion variables}

In conjunction with the aim of this research, return on assets (ROA) is employed as a financial performance measure to compute the contribution on human, organisational and financial capital on disruptive innovations in the form of newly developed products and services, which create firm value. ROA is a profitability measure and argued to be a better proxy than return on equity (ROE). Following previous studies conducted in the context of financial sector (Reed et al., 2006; Nawaz, 2017a) ROA is used a proxy measure for firm's profitability. Following prevous stuides, ROA is computed as the ratio of net income to total assets (Nawaz, 2017b; Nawaz \& Haniffa, 2017; Nawaz, 2017c; Nawaz, 2016a). 
Determinants and consequences of disruptive innovations: evidence from the UK financial services sector

Table 1. R esearch variable definitions

\begin{tabular}{|c|c|c|}
\hline Variables & Proxy & Operationalisation \\
\hline$\frac{\text { Criterion variable }}{\text { Return onAssets }}$ & ROA & Net Income/ Total Assets \\
\hline Predictor variables & \multirow{3}{*}{$\begin{array}{l}\mathrm{FC} \text { Contribution } \\
\mathrm{HC}_{\text {Contribution }} \\
\mathrm{OC}_{\text {Contribution }}\end{array}$} & \\
\hline $\begin{array}{l}\text { Financial Capital } \\
\text { Human Capital }\end{array}$ & & $\begin{array}{l}\text { Capital Employed/Total Assets } \\
\text { Personnel Expenses/Total Assets }\end{array}$ \\
\hline Organisational Capital & & $\begin{array}{l}\text { Difference of Net Income to Personnel } \\
\text { Expenses/ Total Assets }\end{array}$ \\
\hline FirmListing & Firm isting & $\begin{array}{l}\text { Binary Variable: } 1 \text { if the bank is listed, } 0 \\
\text { otherwise }\end{array}$ \\
\hline Audit Quality & AuditQuality & $\begin{array}{l}\text { Binary Variable: } 1 \text { if the bank is audited a } \\
\text { Big4 firms, } 0 \text { otherwise }\end{array}$ \\
\hline
\end{tabular}
KPMG).

Corporate resources namely human capital, organisational capital and financial capital are the independent variables used in this research study. The impact of each of these corporate resources on firm value, measured by the financial performance (i.e. ROA) of the selected banks is analysed.

One may argue that the study includes different types of financial institutions. These institutions follow indifferent banking business models and given the nature of their core business, they may attract different equity providers, hence, their portfolio of assets may vary. Therefore, it is important to consider the impact of bank size. Accordingly, to control for the size bias, the study takes the ratio of total expenditure on human, structural and financial capital to total assets for each bank included in the study. Firm's listing status is a very important factor in financial decision-making. Listed firms are more visible and can attract more investments (Nawaz and Haniffa, 2017). Therefore, it is expected that listing status relate with firm value creation process. Another important variable is the audit quality. It is assumed that firms audited by the big four (Big4) audit firms are considered more transparent hence, are favoured by the investors (Albu et al., 2011; Nawaz, 2017a; Nawaz, 2017b). Accordingly, it is expected that audit qual ity have a direct impact on firm value. The operational isation of all the variables employed in this research arefurther summarised in Table 1. 
Figure 1. Conceptual framework

\begin{tabular}{||l|c|c|}
\hline \multicolumn{1}{|c|}{ Corporate resources } & & Firm value \\
(Profitability)
\end{tabular}

The conceptual framework used in the current research is illustrated in Figure 1. As stated above, the research examines the determinants and consequences of disruptive innovations in the context of financial institutions operating in the UK. Corporate resources viz. human, structural and financial capital are argued to bethe determinants of disruptive innovations. These resources are necessary for any business to create val ue in today's knowl edge-driven economy. The significance of these resources is however, higher in services firms such as banks because of the rapidly increasing competition in the financial services sector.

The significance of financial services sector is even higher in the UK given the contribution of this sector to the UK's economy. Consequences of disruptive innovations are measured in monetary terms. As argued earlier, disnuptive innovations result from and supported by the corporate resources i.e. human, organisational and financial capital, which in turn leads up to higher val ue creation for a firm Thus, a bank with higher stocks of corporate resources is expected to support higher volumes of disruptive innovations that will lead up to higher firm value.

Profitability, proxied by the return on assets (ROA) is used to measure the consequences of disruptive innovations. Firm value in the context of present study refers to profitability, measured by the ROA. The research further controls for firm-related variables such as bank's listing status and audit quality to control for their potential impact on profitability. Listed banks are more visi ble to the potential investors as well as being a publically traded firm; they are subject to further scrutiny because the stakeholders constantly monitor their actions. Similarly, the significance of the quality of auditing (i.e. Big4) in promoting accounting convergence have been submitted (Albu et al., 2011).

In the absence of primary data, this research uses secondary data derived from the annual reports and financial statements of the sampled banks, consistent with the previous studies (Oluwagbemiga et al., 2016). Therefore, the proposed proxies are 
argued to be appropriate in fulfilling the main research objective presented in this research.

\subsection{Research sample}

The study aims to explore the UK financial services sector. With this research objective in mind, various datasets were consulted including, Bank Focus Database (formal ly, Bankscope database), DataStream database, Bank of Engl and Statistical Interactive Database, individual bank's websites and various other publically available resources to extract data for the current research paper. According to the Orbis Bank Focus Database, there are 518 financial institutions (FIs) actively offering a diversified rage of financial products and services to their institutional, private and civic clientele based in the UK and abroad. These financial institutions are further classified into fifteen different categories based on their business model (seeFigure 2 for details).

The categories include; Commercial Banks, Finance Companies, Investment Banks, Real Estate \& Mortgage Banks, Bank Holdings \& Holding Companies, Securities Firms, Investment \& Trust Corporations, Private Banking / Asset Management Companies, Islamic Banks, Clearing \& Custody Institutions, Group Finance Companies, Other Non-banking Credit Institutions, Saving Banks, Cooperative Banks, and Specialized Government Credit Institutions. Less than twenty percent of the initial sample of 518 Fls are listed. Barclays Bank Plc is ranked number one in the UK, based on total assets and equity. 


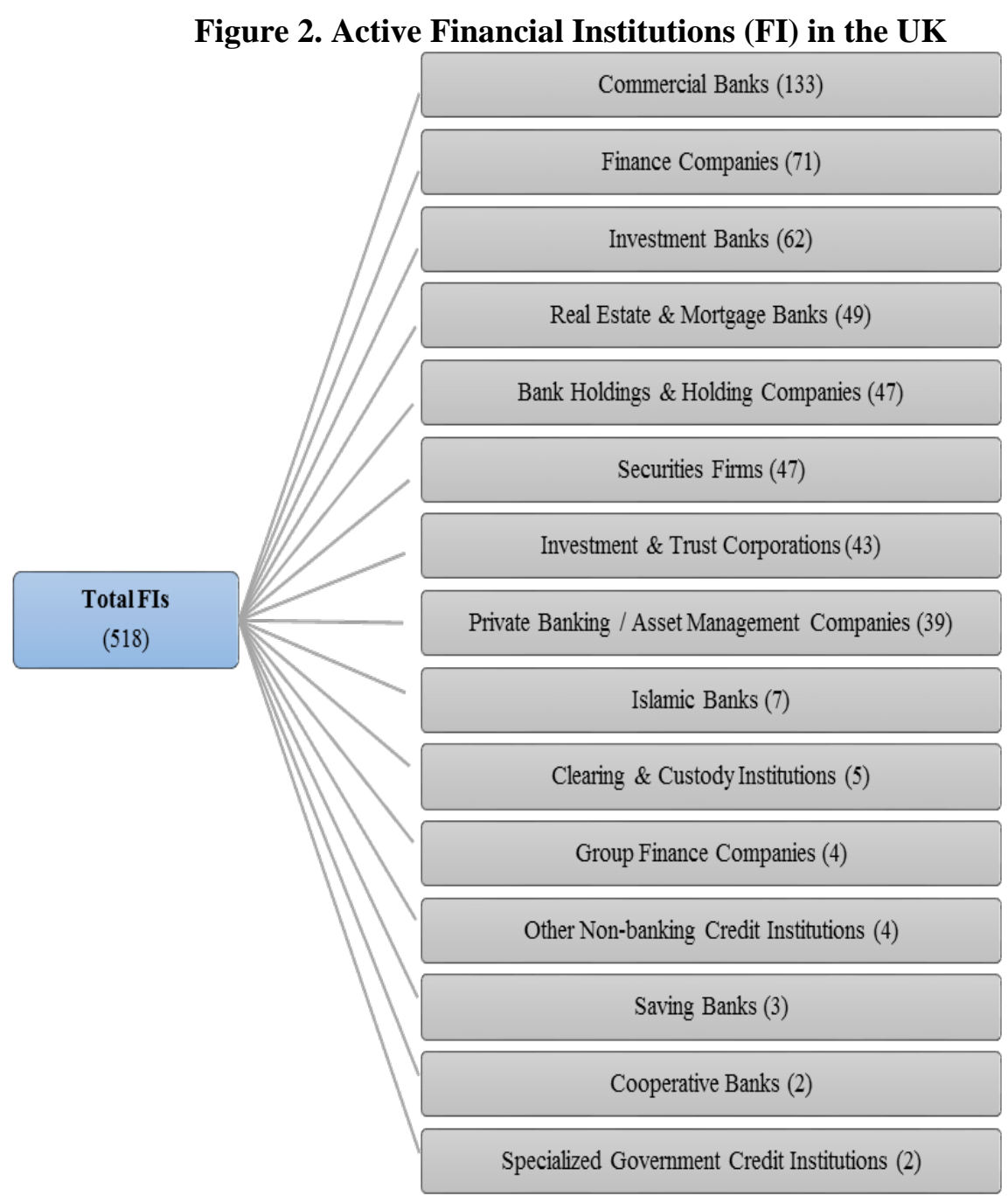

Various filters were applied to the initially selected sample of 518 FIs. Fls with missing and incomplete data were el iminated. The trimmed observations bel onged to the Finance Companies, Clearing \& Custody Institutions, Group Finance Companies, Cooperative Banks, Investment \& Trust Corporations, Specialized Government Credit Institutions, Investment \& Trust Corporations, and Private Banking / Asset Management Companies. After applying all these filters a sample of 211 FIs was selected for further analysis. The detailed characteristics of the selected financial institutions are summarised in Table 2. 
Determinants and consequences of disruptive innovations: evidence from the UK financial services sector

Table 2. Sample characteristics

\begin{tabular}{l|l|l|l}
\hline $\begin{array}{c}\text { Type of Financial } \\
\text { Institution }\end{array}$ & \multicolumn{1}{|c|}{$\begin{array}{c}\text { No. of Financial } \\
\text { Institutions }\end{array}$} & $\begin{array}{c}\text { No. of } \\
\text { Observations }\end{array}$ & $\begin{array}{c}\text { Sample } \\
\text { R epresentation }\end{array}$ \\
\hline Commercial Banks & 110 & 550 & $52 \%$ \\
Investment Banks & 49 & 245 & $23 \%$ \\
Bank Holdings & 46 & 230 & $22 \%$ \\
Islamic Banks* & 6 & 30 & $3 \%$ \\
\hline Total & 211 & 1055 & $100 \%$ \\
\hline
\end{tabular}

Notes *Islamic banks refer to a full-fledge financial intermediary institution which provides financial products and services like any other conventional bank however, such banks are abide by the Islamic law known as Shari' ah. The key features of Islamic banking are (i) interest-free banking, no charge or payment of interest, (ii) profit-and-loss based financing, (iii) probation to finance illicit activities, and co-governance by the Shari'ah scholars.

The study covered a period of five years from 2012 to 2016 . This produced a sample of 1055 observations. Out of 211 FIs 11 were delisted, twenty-two are listed whereas the remaining one hundred and seventy-eight FIs are not listed.

Table 3. Descriptive statistics of criterion and predictor variables

\begin{tabular}{lllll}
\hline \multicolumn{1}{c}{ V ariables } & M ean & \multicolumn{1}{c}{ Std. Dev. } & \multicolumn{1}{c}{ M inimum } & \multicolumn{1}{c}{ M aximum } \\
\hline Observations & 1055 & 1055 & 1055 & 1055 \\
ROA & 0.978 & 1.678 & -1.859 & 3.239 \\
FC Contribution & 0.734 & 0.165 & 0.050 & 1.084 \\
HCContribution & 0.676 & 0.146 & 0.385 & 0.869 \\
OC Contribution & 0.223 & 0.112 & 0.041 & 0.419 \\
Firm & 0.130 & 0.110 & 0 & 1 \\
Auditing & 0.694 & 0.592 & 0 & 1 \\
\hline
\end{tabular}

Notes Seetable 1 for variable definitions.

The descriptive statistics reported in Table 3 indicate that the average contribution of corporate resources; human, organisational and financial capital are $0.73,0.68$, and 0.22 , respectively. The analysis further suggests that financial capital is the main driver of value creation in the UK financial institutions followed by human capital and organisational capita. Similarly, financial performance of the sampled banks is positive with an average retum on assets of 0.98 with minimum and maximum values of -1.86 and 3.24, respectively. The results suggest that sampled banks were able to generate financial profits using their corporate resources. Tuming to the firm-related control variables, it can be seen that around thirteen percent of the banks are listed. Similarly, around seventy percent of the banks are audited by the big-four audit firms, which suggests a high audit quality among UK financial institutions. Turning the focus to Table 4, which displays the correlation matrix. No correlation between dependent and independent variables can be observed. 
Table 4. C orrelation matrix

\begin{tabular}{cccccc}
\hline Variables & $\mathbf{R O A}$ & $\mathbf{F C}$ contribution & $\mathbf{H C}_{\text {contribution }}$ & $\mathbf{O} \mathbf{C}_{\text {contribution }}$ & $\mathbf{F ~ i r m ~}_{\text {Listing }}$ \\
\hline $\mathrm{ROA}$ & 1 & & & & \\
$\mathrm{FC}_{\text {Contribution }}$ & $0.2279 * * *$ & & & & \\
$\mathrm{HC}_{\text {Contribution }}$ & 0.0887 & $-0.1685^{* *}$ & & & \\
$\mathrm{OC}_{\text {Contribution }}$ & $0.2999^{* * *}$ & $0.2959^{* * *}$ & $0.1595^{* *}$ & & \\
Firm $_{\text {isting }}$ & $0.1308^{*}$ & $-0.1203^{*}$ & 0.0306 & -0.0041 & \\
Audit & 0.0716 & -0.0762 & 0.0533 & $-0.1516^{* *}$ & $-0.1202^{*}$ \\
\hline Notes: $* * * \mathrm{p}<0.01, * * \mathrm{p}<0.05 * \mathrm{p}<0.1$. & & &
\end{tabular}

Notes: $* * * p<0.01, * * p<0.05, * p<0.1$.

\section{Corporate resources, disruptive innovations and firm value}

Three separate regression models are used to analyse the relationship between corporate resources viz. financial capital, human capital, and organisational and firmprofitability, measured by the financial performance (i.e. ROA) of the sampled banks. The mathematical presentation of the research models is provided in three separate equations bel ow.

Model 1:

Profitability $_{(\text {ROA) }}=\alpha+\beta 1 F C_{\text {Contibution }}+\beta 2$ Firm $_{\text {Listing }}+\beta 3$ Audit Quality $+\varepsilon$

Model 2:

Profitability $_{(\text {ROA) }}=\alpha+\beta 1 H C_{\text {Contibution }}+\beta 2$ Firm $_{\text {Listing }}+\beta 3$ Audit Quality $+\varepsilon$

Model 3:

Profitability $_{(\text {ROA })}=\alpha+\beta 10 C_{\text {Contribution }}+\beta 2$ Firm $_{\text {Listing }}+\beta 3$ Audit Quality $+\varepsilon$

Where;

Profitability $($ ROA) $=$ Financial performance, a proxy for firmvalue (ROA),

$\mathrm{FC}_{\text {Contibution }}=$ Financial capital contribution,

$\mathrm{HC}_{\text {Contribution }}=$ Human capital contribution,

$\mathrm{OC}_{\text {Contribution }}=$ Organisational capital contribution,

Firm $_{\text {isting }}=$ Listing status of the firm, and

Audit Quality $=$ Audit quality.

Table 5. R egression analysis of ROA on human, organisational, financial capital and control variables

\begin{tabular}{llllll}
\hline & & & M odel 1 & M odel 2 & M odel 3 \\
\hline Variables & Hypothesis & Predicted Sign & ROA & ROA & ROA \\
\hline Observations & & & 1055 & 1055 & 1055 \\
$\mathrm{FC}_{\text {Contribution }}$ & $\mathrm{H}_{1}$ & + & $5.306^{* * *}$ & & \\
$\mathrm{HC}_{\text {Contribution }}$ & $\mathrm{H}_{2}$ & + & & $2.614^{* * *}$ &
\end{tabular}


Determinants and consequences of disruptive innovations: evidence from the UK financial services sector

\begin{tabular}{|c|c|c|c|c|c|}
\hline & & & M odel 1 & Model 2 & M odel 3 \\
\hline $\mathrm{OC}_{\text {Contribution }}$ & $\mathrm{H}_{3}$ & + & & & 0.889 \\
\hline Firm $_{\text {isting }}$ & & +- & $0.470^{* *}$ & $0.577 * * *$ & $0.452^{* *}$ \\
\hline Audit Quality & & +- & $0.575^{* * *}$ & $0.492^{*}$ & 0.350 \\
\hline Constant & & & $-1.166 * * *$ & $-1.805^{* * *}$ & -0.289 \\
\hline Adjusted $R^{2}$ & & & 0.137 & 0.084 & 0.025 \\
\hline
\end{tabular}

Notes $* * * p \varangle 0.01, * * p \varangle 0.05, * p \varangle 0.1$.

Results from model 1, which measures the contributing impact of financial capital on value creation in the financial institutions operating in the UK financial sector are reported in column 4 of Table 5 . The regression analysis indicates a strong positive relationship at $1 \%$ significance level between financial capital and firm performance, measure by ROA, in the expected direction. Hence, hypothesis $\left(\mathrm{H}_{1}\right)$ is supported.

Results from model 2, which measures the contributing impact of human capital on value creation in the financial institutions operating in the UK financial sector are reported in column 5 of Table 5. The regression analysis indicates a strong positive relationship at $1 \%$ significance level between human capital and firm performance, measure by ROA, in the expected di rection. Hence, hypothesis $\left(\mathrm{H}_{2}\right)$ is supported.

An interpretation of the results in the context of the current study is as follows. Sampled financial institutions (FIs) hired individuals who possess the knowledge and abilities related to finance. Employees exploited their attributes either to develop new products and services or to cope with the existing ones, including innovative products, claimed as disruptive innovations. The efficient execution of these functions crated value for the FIs, measured by return on assets. Thus consistent with the assumption it can be argued that FIs expenses on hiring these talents contributed to sustainable financial performance by the sampled FIs during the study period. Although most of the UK FIs profoundly promoted the so-called innovative products such as CDOs. It should be noted however that the study is not focused on whether these employees contributed in developing any specific products that have caused any harm to the financial sector; instead, it solely explores the role of human capital in creating value for the firms.

Finally, results from mode 3 , which measures the contributing impact of organisational capital on value creation in the financial institutions operating in the UK financial sector are reported in column 6 of Table 5. The regression analysis indicates no statistically significant relationship between ROA and organisational capital. Hence, there is not enough statistical evidence to support hypothesis $\left(\mathrm{H}_{3}\right)$. As argued above, organisational capital is equally essential in the value creation 
process however, the weak statistical evidence does provide support to this argument

Although the results in model 2 suggested that human capital is necessary to create value however, the affordability of talents is subject to sufficient financial resources. In other words, human capital cannot work without the supporting capital and especially financial capital resources. To conclude, it is argued that human and financial capital resources determine the value creation, reflected in strong financial performance.

Tuming to the firm-related controlled variables, it can be seen that firm's listing status relates positively with ROA in all three models, which is consistent with the arguments presented in the paper above that listing status improves firm's profitability. Similarly, audit quality (i.e. Big4) relates significantly with ROA in model 1 and 2 , which implies that audit quality improves firm value.

\section{Conclusion}

The aim of this study is to explore the determinants and consequences of distuptive innovations in the UK financial services sector. Building on the assumption that intangi ble and tangible corporate assets are indi spensable to create and sustain firm value in today's knowledge-intensive era; the study further argues that corporate resources such as financial capital, human capital, and organisational capital are essential to create value. With this research objective in mind, the study analysed the UK financial services sector by selecting a research sample to test the assumptions. The study covered a period of five years from 2012 to 2016 . A sample of 1055 observations belonging to 211 financial institutions operating within the UK financial services sector is used in the regression analysis to test the extended research hypotheses. The paper makes informed suggestions for the financial institutions operating in the UK and abroad. The results observed in the present study will potentially enhance the understanding of the international audiences on the banking business model practiced by the UK-based financial institutions.

The major contribution of this paper is to provide novel insights into the value creation process in one of the largest financial services providers in the world -the UK. In doing so, the paper exploited various properties of the UK financial sector at first The paper then showcased the nature and type of financial institutions operating within the UK financial services industry. Third, the paper identified the corporate resources essential for value creation in today's knowledge-intensive era and finally, the study performed regression analyses on the selected financial institutions to test the extended hypotheses. The study submit that financial and human capital resources drive value, proxied by the financial performance of financial institutions operating in the UK. Thus, it is argued that the financial 
institutions in the UK exploit their stocks of financial and human capital resources to create value.

The results observed in this study have larger implications. The results can potential ly help the UK financial services sector to adjust their current strategies by capital ising on the corporate resources such as human and financial capital in order to remain competitive in the event of the looming divorce between the UK and the EU. The knowledge embedded in the human capital resources (i.e. people/employees), in particular, is the main corporate assets that has the potential to save the UK's finance industry in the current political and economic distress. Financial institutions should implement strategies to retain this brainpower because brain-drain will trigger another crisis in the industry.

At the same time, the political instability offers an adroit opportunity for the rival institutions (i.e international financial institutions) to attract the brainpower by offering them better economic incentives. This will potentially help the hiring institutors to lour larger sums of money by exploiting the relational capital (especially, links with larger corporate and individuals currently banking with the UK-based banks) of the newly hired employees. If this happens, the UK financial services sector may lose its competitive advantage to its rivals on both the financial and human capital front as submitted by Nawaz (2016b).

Constrained by the data availability, this study employed financial performance measure (i.e. ROA) and focused on the accounting-based performance The future research may use both accounting- and market-based performance measures such as market-to-book ratios (MBT-ratio) and Tobin's Q (Q-ratio) to determine the impact of disruptive innovations on sustainability of the financial services industry. Similarly, future research may replicate this study while using the primary data collected through interviews or case study based approach, which may offer further insights into the phenomenon. Another potential avenue for future research is to examine the determinants and consequences of disruptive innovations in the financial and non-financial sector. These chasms have been highlighted for the future researchers. 


\section{R eferences}

Albu, C.N., Albu, N., Pali-Pista, S.F. \& Vladu, D.C. (2011) „The power and the glory of Big 4: A Research note on independence and competence in the context of IFRS implementation", Accounting and Management Information Systems, vol. 10, no. 1: 43-54.

Charitou, C.D. \& Markides, C.C. (2002) "Responses to disnuptive strategic innovation", MIT Sloan Management Review, vol. 44, no. 2: 55-64.

Christensen, C. (2013), The innovator's dilemma: when new technologies cause great firms to fail, Harvard Business Review Press.

Christensen, C.M., Raynor, M.E. \& McDonald, R. (2015) „What is disruptive innovation", Harvard Business Review, vol. 93, no. 12: 44-53.

Crotty, J. (2009) "Structural causes of the global financial crisis: a critical assessment of the "new financial architecture'", Cambridge J ournal of Economics, vol. 33, no. 4: 563-580.

Edmonds, T. (2018) „Brexit \& financial services, House of Commons Library, briefing paper, No. 07628", Available online (retrieved on 5 May 2018): file:///C:/Users/tnawaz/Downloads/CBP-7628.pdf.

Edvinsson, L. \& Sullivan, P. (1996) „Developing a model for managing intellectual capital", European Management J ournal, vol. 14, no. 4: 356-364.

Nagy, D., Schuessler, J. \& Dubinsky, A. (2016) "Defining and identifying disruptive innovations", Industrial Marketing Management, vol. 57: 119126.

Nawaz, T. (2017a) „Exploring the Nexus Between Human Capital, Corporate Govemance and Performance: Evidence from Islamic Banks", J ournal of Business Ethics, DOI: 10.1007/s10551-017-3694-0.

Nawaz, T. (2017b) „Momentum investment strategies, corporate governance and firm performance: an analysis of Islamic banks", Corporate Governance: The International J ournal of Business in Society, vol. 17, no. 2: 192-211.

Nawaz, T. \& Haniffa, R. (2017) „Determinants of financial performance of Islamic banks: An intellectual capital perspective", J ournal of Islamic Accounting and Business Research, vol. 8, no. 2: 130-142.

Nawaz, T. (2017c) „Intellectual capital, financial crisis and performance of Islamic banks: Does Shariah governance matter?", International J ournal of Business and Society, vol. 18, no. 1: 211-226.

Nawaz, T. (2017d) "I slamic Banking: An Ultimate Source of Financial Inclusion”, International Journal of Social, Behavioral, Educational, Economic, Business and Industrial Engineering, vol. 11, no. 8: 2047-2050.

Nawaz, T. (2017e) „Human capital development in socio-economic malaise: evidence from the UK", International J ournal of Learning and Intellectual Capital, vol. 14, no. 1: 24-46.

Nawaz, T. (2016a) "Determinants of sustainable growth: a comparative analysis of conventional and Islamic banks", Corporate Ownership \& Control, vol. 4, no. 1: 403-413. 
Nawaz, T. (2016b) „Expatriation in the age of austerity: an analysis of capital mobilization strategies of self-initiated expatriates", in the Handbook of Research on Human Resources Strategies for the New Millennial Workforce, pp. 177-199, IGI Global, USA.

Nawaz, T. (2015) Ethical Banking in the Land of Redistributive Policies, Scholars Press, Saarbruchen, Germany.

Nawaz, T. (2013a) „How serious is the Erudite Shariah-compliant Business in Europe? Evolution, Pivotal Challenges and the way forward", European J ournal of Business and Management, vol. 4, no. 6: 226-235.

Nawaz, T. (2013b) „Blind-trust - a Pave Stone for Islamic Financial Institutions", Research J ournal of Finance and Accounting, vol. 4, no. 6: 226-235.

Nawaz, T. \& Goj, T. (2013) „Intellectual Capital: A Synthesis of Current Research with Special Reference to Islamic Banking and Finance", International J ournal of Business and Management Studies, vol. 2, no. 1: 303-317.

Oluwagbemiga, O.E., Isaiah, O.O. \& Esiemogie, I.P. (2016) „The relationship between the risk management practices and financial performance of the Nigerian listed banks", Accounting and Management Information Systems, vol. 15, no. 3: 565-587.

Reed, K.K., Lubatkin, M. \& Srinivasan, N. (2006) „Proposing and testing an intel lectual capital-based view of the firm", J ournal of Management Studies, vol. 43, no. 4: 867-893.

Rhodes, C. (2018) „Financial Services: contribution to the UK economy, House of Commons Library, briefing paper, No. 6193", Available online: file://C:/Users/tnawaz/Downloads/SN06193.pdf (retrieved on 5 May 2018).

Subramaniam, M. \& Y oundt, M.A. (2005) „The influence of intel lectual capital on the types of innovative capabilities", Academy of Management J ournal, vol. 48, no. 3: 450-463.

Uzzi, B. (1999) „Embeddedness in the making of financial capital: How social relations and networks benefit firms seeking financing", American Sociological Review, vol. 64, no. 4: 481-505.

Y u, D. \& Hang, C.C. (2010) „A reflective review of disruptive innovation theory”, International Journal of Management Reviews, vol. 12, no. 4: 435-452. 